\title{
Article
}

\section{Ethyl and butyl acetate oxidation over manganese oxides}

\author{
Olívia Salomé G. P. Soares, Raquel P. Rocha, José J.M. Órfão, Manuel F. R. Pereira, \\ José L. Figueiredo * \\ Laboratory of Separation and Reaction Engineering-Laboratory of Catalysis and Materials (LSRE-LCM), Faculty of Engineering, University of Porto, Rua \\ Dr. Roberto Frias s/n, 4200-465 Porto, Portugal
}

\section{A R T I C L E I N F O}

\section{Article history:}

Received 7 November 2017

Accepted 21 November 2017

Published 5 January 2018

\section{Keywords:}

Volatile organic compound

Ethyl acetate

Butyl acetate

Manganese oxide

Catalytic oxidation

\begin{abstract}
A B S T R A C T
Mangenese oxides were synthesized using two new methods, a novel solvent-free reaction and a reflux technique, that produced cryptomelane-type products (K-OMS-2). Oxides were also synthesized using conventional methods and all specimens were applied to the oxidation of ethyl acetate and butyl acetate, acting as models for the volatile organic compounds found in industrial emissions. The catalysts were also characterized using $\mathrm{N}_{2}$ adsorption, X-ray diffraction, scanning electron microscopy, temperature programmed reduction and X-ray photoelectron spectroscopy. Each of the manganese oxides was found to be very active during the oxidation of both esters to $\mathrm{CO}_{2}$, and the synthesis methodology evidently had a significant impact on catalytic performance. The K-OMS-2 nanorods synthesized by the solvent-free method showed higher activity than K-OMS-2 materials prepared by the reflux technique, and samples with cryptomelane were more active than those prepared by the conventional methods. The catalyst with the highest performance also exhibited good stability and allowed $90 \%$ conversion of ethyl and butyl acetate to $\mathrm{CO}_{2}$ at 213 and $202{ }^{\circ} \mathrm{C}$, respectively. Significant differences in the catalyst performance were observed, clearly indicating that K-OMS-2 nanorods prepared by the solvent-free reaction were better catalysts for the selected VOC oxidations than the mixtures of manganese oxides traditionally obtained with conventional synthesis methods. The superior performance of the K-OMS-2 catalysts might be related to the increased average oxidation state of the manganese in these structures. Significant correlations between the catalytic performance and the surface chemical properties were also identified, highlighting the K-OMS-2 properties associated with the enhanced catalytic performance of the materials.
\end{abstract}

(C) 2018, Dalian Institute of Chemical Physics, Chinese Academy of Sciences. Published by Elsevier B.V. All rights reserved.

\section{Introduction}

Volatile organic compounds (VOCs) are recognized as major contributors to air pollution. These compounds are toxic and can also act as precursors to the formation of ground level ozone and photochemical smog. Because of concerns regarding the continual increases in VOC emissions, their release into the environment is controlled by stringent regulations. In this context, catalytic oxidation is considered a promising technology for the control of VOC emissions [1,2]. The efficiency of catalytic

\footnotetext{
* Corresponding author. Tel: +351-225-081998; Fax: +351-225-081449; E-mail: jlfig@fe.up.pt

This work was supported by project “AIProcMat@N2020-Advanced Industrial Processes and Materials for a Sustainable Northern Region of Portugal 2020", with the reference NORTE-01-0145-FEDER-000006, supported by Norte Portugal Regional Operational Programme (NORTE 2020), under the Portugal 2020 Partnership Agreement, through the European Regional Development Fund (ERDF) and of Project P0CI-01-0145-FEDER-006984 Associate Laboratory LSRE-LCM funded by ERDF through COMPETE2020-Programa Operacional Competitividade e Internacionalizacao (POCI) - and by national funds through FCT-Fundacao para a Ciencia e a Tecnologia. R.P. Rocha acknowledges FCT grant SFRH/BD/95411/2013. DOI: 10.1016/S1872-2067(17)62986-3 | http://www.sciencedirect.com/science/journal/18722067 | Chin. J. Catal., Vol. 39, No. 1, January 2018
} 
oxidation depends greatly on the type of catalyst employed, and the most effective catalysts will be determined by the properties of the effluent to be treated, including chemical composition, flow rate, presence of poisons or/and inhibitors, and by inlet temperature constraints.

The most commonly used catalysts for the catalytic oxidation of VOCs are supported noble metals (Pt or Pd) [3,4], which are generally considered to be more active than metal oxides [5-8]. However, $\mathrm{Co}, \mathrm{Cu}, \mathrm{Ni}$ and especially $\mathrm{Mn}$ oxides have also demonstrated high catalytic activities [9-11]. These oxides have the additional advantages of lower cost and higher resistance to deactivation by poisoning in comparison to supported noble metals. Manganese oxides $\left(\alpha-\mathrm{MnO}_{2}, \beta-\mathrm{MnO}_{2}\right.$, $\gamma-\mathrm{MnO}_{2}, \mathrm{Mn}_{3} \mathrm{O}_{4}, \mathrm{Mn}_{2} \mathrm{O}_{3}$ ) have been extensively studied as catalysts for the oxidation of many pollutants. The catalytic performance of $\mathrm{MnO}_{x}$ compounds is attributed to the ability of manganese to form oxides with different oxidation states having high oxygen storage capacities [2,12]. Although the nature of the active sites associated with catalytic oxidation is not well understood, several authors attribute the high activity of these oxides to the mixed valence state of the manganese framework and to the higher mobility of lattice oxygen in these compounds, suggesting that lattice oxygen participates in the oxidation process $[13,14]$. Moreover, the presence of structural defects such as cationic vacancies and chemical defects have also been found to improve catalyst performance $[15,16]$.

Among the manganese oxides, cryptomelane (K-OMS-2) is of particular interest due to its open tunnel structure, mixed manganese valence states and highly mobile lattice oxygen. Cryptomelane-type manganese oxide $\left(\mathrm{KMn}_{8} \mathrm{O}_{16}\right)$ was found to be very active during the oxidation of several types of VOCs, and its performance is evidently significantly affected by the presence of other phases, namely $\mathrm{Mn}_{2} \mathrm{O}_{3}$ and $\mathrm{Mn}_{3} \mathrm{O}_{4}$ [17]. The latter improves catalytic performance by increasing the reactivity and mobility of lattice oxygen, while the former has the opposite effect.

The development of fast, simple and low cost methods to produce highly active catalysts for VOC oxidation is still a challenge, considering that this would require the scaled-up production of various materials. The aim of the present work was to prepare stable, efficient manganese oxides for use as catalysts for VOC oxidation. These materials were synthesized using new techniques involving a novel solvent-free reaction or a reflux method to synthesize cryptomelane-type manganese oxides, but also by conventional methods. The goal of this study was to assess the effects of the oxide surface area, morphology, surface reducibility and redox properties on the catalytic performance. These catalysts were tested based on the oxidation of two esters representative of those found in industrial emissions: ethyl and butyl acetate. These esters were selected because the former is among the most studied catalytic oxidation model compounds while there have been few reports of the catalytic oxidation of the latter [18,19]. In addition, esters are generally reported to be the most difficult organic solvents to oxidize completely [20].

\section{Experimental}

\subsection{Catalyst synthesis}

Manganese oxide catalysts were synthesized by different routes. A cryptomelane type (sample $\mathrm{Mn} 1$ ) was prepared using a reflux method [21,22]. Briefly, $11 \mathrm{~g}$ of $\mathrm{Mn}\left(\mathrm{CH}_{3} \mathrm{COOH}\right)$ was dissolved in $40 \mathrm{~mL}$ of water and the $\mathrm{pH}$ of this solution was adjusted with concentrated nitric acid to a value of 3.5. Next, $6.5 \mathrm{~g}$ of $\mathrm{KMnO}_{4}$ was dissolved in $150 \mathrm{~mL}$ of water and this solution was slowly added to the previous mixture. A black precipitate formed upon stirring and the mixture was refluxed at 100 ${ }^{\circ} \mathrm{C}$ for $24 \mathrm{~h}$. The solid was filtered, washed with distilled water, dried in an oven and calcined at $450{ }^{\circ} \mathrm{C}$ in air for $4.5 \mathrm{~h}$. Other samples were prepared by a novel solvent-free solid-state reaction adapted from the procedure described by Ding et al. [23]. The $\mathrm{KMnO}_{4}$ and $\mathrm{Mn}\left(\mathrm{CH}_{3} \mathrm{COOH}\right)_{2}$ were combined at a stoichiometric molar ratio of 2:3 and ball-milled (Mixer Mill MM 200, Retsch, Haan, Germany) for $1 \mathrm{~h}$ at either 5 vibration/s (sample Mn2) or 10 vibration/s (sample Mn3). In each case, the resulting black solid was transferred to a capped bottle and heated at $80^{\circ} \mathrm{C}$ for $4 \mathrm{~h}$. The product was then washed with water until the wash water was neutral, dried at $100{ }^{\circ} \mathrm{C}$ overnight and finally calcined at $450{ }^{\circ} \mathrm{C}$ for $4.5 \mathrm{~h}$. Traditional methods were also used to synthesize four additional samples via the direct calcination of the $\mathrm{Mn}\left(\mathrm{CH}_{3} \mathrm{COOH}\right)$ at $450{ }^{\circ} \mathrm{C}$ for $4.5 \mathrm{~h}$ in two different ovens (vertical (sample $\mathrm{MnCV}$ ) or horizontal (sample $\mathrm{MnCH}$ )) and by precipitation with $\mathrm{NaOH}$ using $\mathrm{Mn}\left(\mathrm{CH}_{3} \mathrm{COO}\right)_{2}$ (sample MnPA) or $\mathrm{Mn}\left(\mathrm{NO}_{3}\right)_{2}$ (sample MnPN) as the precursor, based on a procedure described elsewhere [24].

\subsection{Catalyst characterization}

Nitrogen adsorption isotherms were acquired at $-196{ }^{\circ} \mathrm{C}$ with a Quantachrome NOVA 4200e multi-station apparatus to evaluate the textural properties of the manganese oxide samples. The surface areas of the oxides $\left(S_{\mathrm{BET}}\right)$ were determined according to the Brunauer-Emmett-Teller method. The structure and phase purity of each prepared material was analysed by X-ray diffraction (XRD) with a Philips X'Pert MPD diffractometer $\left(\mathrm{Cu}-K_{\alpha}, \lambda=0.15406 \mathrm{~nm}\right)$. Data were collected over the range of $2 \theta=20^{\circ}-80^{\circ}$. The crystallite sizes in the catalysts were determined by Rietveld refinement.

Scanning electron microscopy (SEM)/energy dispersive spectroscopy (EDS) observations were performed using a high resolution (Schottky) environmental SEM instrument in conjunction with X-Ray microanalysis and electron backscattered diffraction (Quanta 400 FEG ESEM/EDAX Genesis X4M).

The reactivities of the oxygen species present in the manganese oxides were assessed based on temperature programmed reduction (TPR) data obtained with a fully automated AMI-200 Catalyst Characterization apparatus (Altamira Instruments) equipped with a thermal conductivity detector (TCD) to determine the hydrogen consumption during the reduction step. In a typical run, $0.050 \mathrm{~g}$ of the sample was placed in a U-shaped quartz tube located inside an electrical furnace and heated from room temperature to $600{ }^{\circ} \mathrm{C}$ at $5{ }^{\circ} \mathrm{C} \mathrm{min}-1$ under a flow of $5 \mathrm{vol} \% . \mathrm{H}_{2} / \mathrm{Ar}$ at $30 \mathrm{~cm}^{3} \mathrm{~min}^{-1}$, while the hydrogen consumption was monitored using the TCD. At the end of each 
analysis, hydrogen calibration was carried out at $50^{\circ} \mathrm{C}$.

The X-ray photoelectron spectroscopy (XPS) analyses were performed using a Kratos AXIS Ultra HAS. Data were acquired with a monochromatic Al $K_{\alpha}$ X-ray source $(1486.7 \mathrm{eV})$ operating at $15 \mathrm{kV}(90 \mathrm{~W})$ in the fixed analyser transmission (FAT) mode with a pass energy of $40 \mathrm{eV}$ for regions of interest and 80 $\mathrm{eV}$ for surveying.

\subsection{Experimental procedures}

The catalytic oxidation of the VOCs was performed under atmospheric pressure in a fixed-bed reactor consisting of a U-shaped quartz reactor ( $6 \mathrm{~mm}$ internal diameter) inside a temperature-controlled electric furnace. In preparation for each run, $50 \mathrm{mg}$ of catalyst was mixed with an inert material (carborundum) of the same particle size as the catalyst (0.2-0.5 $\mathrm{mm}$ ) to minimize thermal effects. Prior to each trial, the catalyst was pre-treated in air at $400{ }^{\circ} \mathrm{C}$ for $1 \mathrm{~h}$. The oxidation experiment was then initiated using a VOC concentration of 1000 $\mathrm{mg} \mathrm{cm}^{-3}$ and a space velocity of $53,050 \mathrm{~h}^{-1}$ in conjunction with a total feed flow rate of $500 \mathrm{~cm}^{3} \mathrm{~min}^{-1}$. The reaction was carried out in two cycles consisting of increasing and decreasing temperature at a heating/cooling rate of $2.5^{\circ} \mathrm{C} \mathrm{min}^{-1}$.

The composition of the gas stream was determined by gas chromatography, using a Master GC Dani equipped with a flame ionization detector and by a $\mathrm{CO}_{2}$ non-dispersive infrared (NDIR) sensor (Vaisala GMT220). The conversion to $\mathrm{CO}_{2}\left(X_{\mathrm{CO} 2}\right)$ was calculated as $X_{\mathrm{CO} 2}=F_{\mathrm{CO} 2} /\left(v \cdot F_{\mathrm{VOC}, \text { in }}\right)$, where $F_{\mathrm{Voc}, \text { in }}$ is the inlet molar flow rate of the VOC, $F_{\mathrm{CO} 2}$ is the outlet molar flow rate of $\mathrm{CO}_{2}$ and $v$ is the number of carbon atoms in the VOC molecule ( $v=4$ for ethyl acetate and $v=6$ for butyl acetate). Selected experiments were carried out in duplicate and the results were founded to be reproducible with a maximum error of $1 \%$.

\section{Results and discussion}

\subsection{Characterization}

\subsubsection{Specific surface area}

The BET surface areas $\left(S_{\mathrm{BET}}\right)$ of the manganese oxide catalysts are provided in Table 1 . The nitrogen adsorption-desorption isotherms of the materials prepared by the same methodology were found to be similar, and the materials had surface areas between 10 and $120 \mathrm{~m}^{2} \mathrm{~g}^{-1}$. The samples prepared by solid-state reaction (Mn2 and Mn3) had the highest surface areas, especially the Mn3, which was prepared using the highest milling vibrational rate, while all the other samples had very low surface areas. Ding et al. [23] studied K-OMS-2 specimens prepared by a solvent-free method and found that these materials had $S_{\text {BET }}$ much higher than those prepared by reflux. The samples prepared by calcination of the precursor ( $\mathrm{MnCV}$ and $\mathrm{MnCH}$ ) or by precipitation (MnPN and MnPA) had the lowest surface areas.

\subsubsection{Structure and morphology}

The effect of the synthesis methodology on the crystallization of the manganese oxides was assessed based on XRD anal-
Table 1

Data from the characterization of manganese oxide by nitrogen adsorption, XRD and TPR.

\begin{tabular}{|c|c|c|c|c|c|}
\hline Sample & $\begin{array}{c}S_{\mathrm{BET}} \\
\left(\mathrm{m}^{2} \mathrm{~g}^{-1}\right)\end{array}$ & $\begin{array}{l}\text { Crystalline } \\
\text { phases } \\
\text { (XRD) }\end{array}$ & $\begin{array}{c}\text { Crystallite } \\
\text { sizes (nm) } \\
\text { (XRD) }\end{array}$ & $\begin{array}{c}\mathrm{H}_{2} \text { consumption } \\
\left(\mu \mathrm{mol} \mathrm{g}^{-1}\right) \\
(\mathrm{TPR})\end{array}$ & $\begin{array}{l}T_{\text {peakmax }} \\
\left({ }^{\circ} \mathrm{C}\right) \\
\text { (TPR) }\end{array}$ \\
\hline \multirow[t]{2}{*}{ Mn1 } & 22 & $\mathrm{KMn}_{8} \mathrm{O}_{16}(74 \%)$ & 29 & 698 & 350 \\
\hline & & $\alpha-\mathrm{MnO}_{2}(26 \%)$ & 39 & & \\
\hline Mn2 & 96 & $\mathrm{KMn}_{8} \mathrm{O}_{16}$ & 18 & 1003 & 320 \\
\hline \multirow[t]{2}{*}{$\mathrm{Mn} 3$} & 120 & $\mathrm{KMn}_{8} \mathrm{O}_{16}(82 \%)$ & 10 & 604 & 305 \\
\hline & & $\alpha-\mathrm{MnO}_{2}(18 \%)$ & 16 & & \\
\hline \multirow[t]{3}{*}{$\mathrm{MnCH}$} & 10 & $\mathrm{Mn}_{3} \mathrm{O}_{4}(68 \%)$ & 30 & 351 & 430 \\
\hline & & $\mathrm{Mn}_{5} \mathrm{O}_{8}(22 \%)$ & 23 & & \\
\hline & & $\mathrm{Mn}_{2} \mathrm{O}_{3}(10 \%)$ & 34 & & \\
\hline \multirow[t]{3}{*}{$\mathrm{MnCV}$} & 11 & $\mathrm{Mn}_{3} \mathrm{O}_{4}(66 \%)$ & 34 & 333 & 413 \\
\hline & & $\mathrm{Mn}_{2} \mathrm{O}_{3}(30 \%)$ & 31 & & \\
\hline & & $\mathrm{Mn}_{5} \mathrm{O}_{8}(4 \%)$ & 27 & & \\
\hline \multirow[t]{2}{*}{ MnPA } & 22 & $\mathrm{Mn}_{3} \mathrm{O}_{4}(81 \%)$ & 43 & 321 & 455 \\
\hline & & $\mathrm{Mn}_{5} \mathrm{O}_{8}(19 \%)$ & 28 & & \\
\hline \multirow[t]{2}{*}{$\mathrm{MnPN}$} & 16 & $\mathrm{Mn}_{3} \mathrm{O}_{4}(95 \%)$ & 41 & 339 & 420 \\
\hline & & $\mathrm{Mn}_{5} \mathrm{O}_{8}(5 \%)$ & 43 & & \\
\hline
\end{tabular}

ysis, and the associated data are summarized in Table 1, while Fig. 1 presents XRD patterns of the materials. Significant differences are evident between these patterns, indicating the presence of different manganese oxide phases. As expected, cryptomelane phases were obtained in the specimens prepared by reflux (Mn1) and solid state reaction methods $(\mathrm{Mn} 2$ and $\mathrm{Mn} 3)$. The Mn2 consisted of a pure cryptomelane phase $\left(\mathrm{KMn}_{8} \mathrm{O}_{16}\right)$, whereas the $\mathrm{Mn} 1$ and $\mathrm{Mn} 3$ were mixtures of $\mathrm{KMn}_{8} \mathrm{O}_{16}$ and $\alpha-\mathrm{MnO}_{2}$. Some unidentified peaks in these patterns can possibly be ascribed to the presence of K [25]. Comparing the XRD patterns of samples the Mn1, Mn2 and Mn3, the latter exhibits more peak broadening, implying smaller crystallite sizes in this specimen. The crystallite domain sizes in the cryptomelane-type materials were in fact quite different; samples Mn1, Mn2 and Mn3 had crystallite sizes (as calculated by Rietveld refinement using the [211] plane) of 29, 18 and $10 \mathrm{~nm}$,

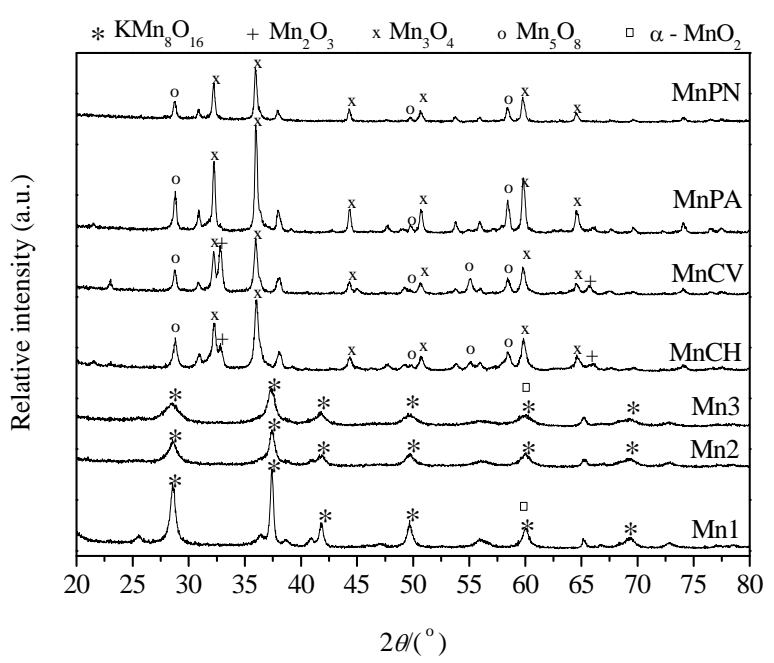

Fig. 1. XRD patterns of the synthesized materials. 

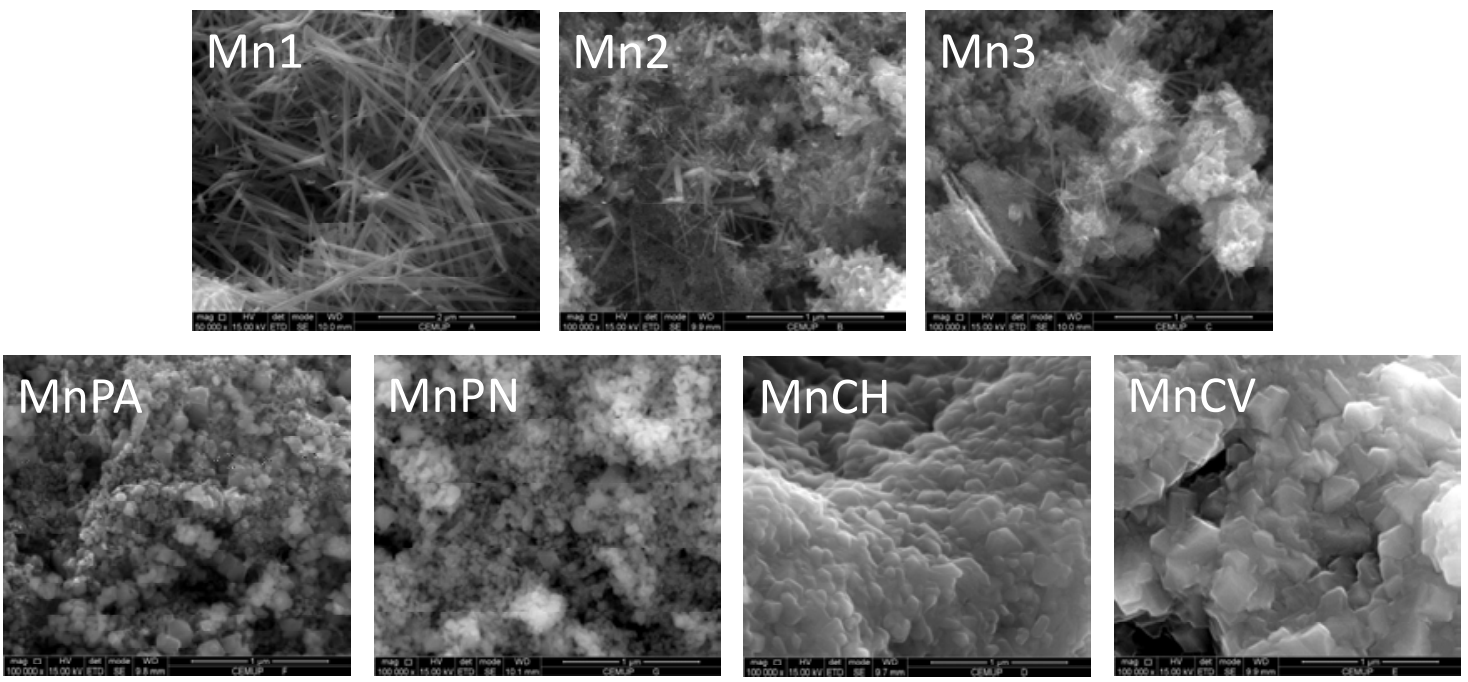

Fig. 2. SEM micrographs of the manganese oxide catalysts.

respectively. These values are in good agreement with data reported by Schurz et al. [26], who also obtained crystal sizes between 10 and $30 \mathrm{~nm}$ for cryptomelane samples. It is clear that the crystal size decreases with increases in the milling vibration process, as smaller crystals were obtained in the Mn3. The samples prepared by thermal decomposition of the precursor ( $\mathrm{MnCH}$ and $\mathrm{MnCV}$ ) evidently contained varying amounts of $\mathrm{Mn}_{3} \mathrm{O}_{4}, \mathrm{Mn}_{5} \mathrm{O}_{8}$ and $\alpha-\mathrm{Mn}_{2} \mathrm{O}_{3}$, with $\mathrm{Mn}_{3} \mathrm{O}_{4}$ present in the highest concentrations. This phase was also predominant in the samples prepared by precipitation with sodium hydroxide (MnPA and MnPN), although only $\mathrm{Mn}_{3} \mathrm{O}_{4}$ and $\mathrm{Mn}_{5} \mathrm{O}_{8}$ were present in those materials as additional phases. Crystal sizes in the range of 30 to $40 \mathrm{~nm}$ were observed for these samples.

Fig. 2 shows SEM micrographs of the materials. The samples synthesized by the solid-state reaction method exhibit homogeneous nanorod morphologies. These nanorods are smaller in the Mn3 compared with the material obtained using the reflux method (Mn1), which instead shows a fibrous morphology, typical of cryptomelane prepared by this method. The diameters of these nanorods are in the range of 10-20 nm, in agreement with the particle sizes (10 and $18 \mathrm{~nm}$ for $\mathrm{Mn} 3$ and $\mathrm{Mn} 2$, respectively) calculated from the XRD patterns. These nanorods were therefore much smaller than those in the sample prepared by the reflux approach (Mn1). In these SEM images,
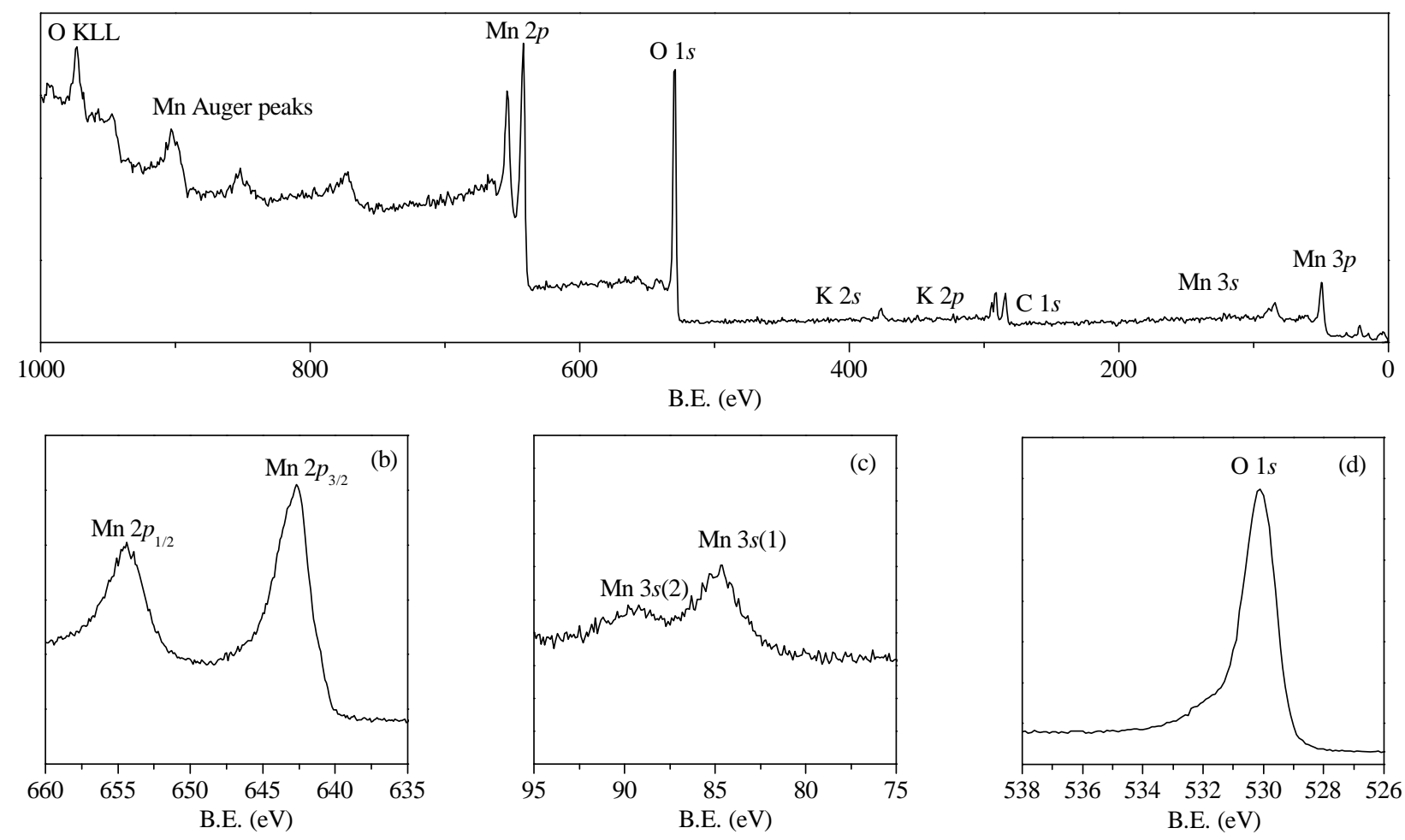

Fig. 3. XPS spectra obtained from the Mn1 sample. (a) survey spectrum; (b) Mn 2p; (c) Mn 3s; (d) $01 s$. 
the structure of the Mn3 is finer than that of the Mn2. This is consistent with the BET measurements, because smaller particle sizes will usually result in higher surface areas. The samples prepared with $\mathrm{KMnO} 4$ (Mn1, Mn2 and Mn3) show different morphologies from the others. Samples $\mathrm{MnCH}$ or $\mathrm{MnCV}$ have similar homogeneous surface morphologies with prismatic-shaped particles, while MnPA and MnPN, which were prepared by the precipitation method, present different surface morphologies. These results demonstrate that the precursor used in the precipitation method affects the morphology and the structure of the resulting manganese oxide. MnPA has a very heterogeneous surface with prismatic particles having widely different sizes, while the MnPN shows a more homogeneous surface.

\subsubsection{Manganese valency and reducibility}

XPS data were acquired to investigate the manganese oxidation state on the oxide surfaces. Fig. 3(a) presents the XPS survey spectrum acquired using the Mn1 specimen (which was similar to those obtained from the other samples) over the binding energy range from 0 to $1000 \mathrm{eV}$. Characteristic Mn $2 p$, Mn $3 s$, Mn $3 p$ and $01 s$ core level signals are observed, as well as Auger signals from $\mathrm{Mn}$ and $\mathrm{O}$. The $\mathrm{Mn}: \mathrm{O}$ atomic ratios on the specimen surfaces (Table 2) varied between 0.49 and 0.56 , with the samples prepared by the solvent-free reaction and reflux techniques (Mn1, Mn2 and Mn3) having lower values. The shape of the $01 s$ spectra suggests the presence of overlapping peaks generated by different oxygen species (Fig. 3(d)). In the spectrum of each sample, the most intense peak appears in the binding energy range between 529.9 and $530.3 \mathrm{eV}$, typically associated with lattice oxygen $\left(\mathrm{O}^{2-}\right)$. This is therefore believed to be the predominant 0 species in these manganese oxides. At higher binding energies, the presence of surface adsorbed oxy-
Table 2

Data from the surface characterization of the manganese oxides as determined by XPS.

\begin{tabular}{lcccccc}
\hline Sample & $\begin{array}{c}\mathrm{C} 1 s \\
\text { (at\%) }\end{array}$ & $\begin{array}{c}\text { O 1s } \\
\text { (at\%) }\end{array}$ & $\begin{array}{c}\text { K } 2 p 1+2 p 3 \\
\text { (at\%) }\end{array}$ & $\begin{array}{c}\text { Mn } 2 p 3 \\
\text { (at\%) }\end{array}$ & Mn/O & AOS \\
\hline Mn1 & 16.4 & 52.0 & 4.6 & 27.0 & 0.52 & 3.7 \\
Mn2 & 21.0 & 50.3 & 4.2 & 24.5 & 0.49 & 3.7 \\
Mn3 & 18.5 & 52.0 & 3.4 & 26.1 & 0.50 & 3.6 \\
MnCH & 25.6 & 47.7 & 0.0 & 26.7 & 0.56 & 2.8 \\
MnCV & 25.2 & 48.1 & 0.0 & 26.7 & 0.56 & 2.7 \\
MnPA & 24.7 & 48.6 & 0.0 & 26.7 & 0.55 & 2.7 \\
MnPN & 24.8 & 48.3 & 0.0 & 26.9 & 0.56 & 2.6 \\
\hline
\end{tabular}

gen $\left(\mathrm{O}_{2}{ }^{2-}\right.$ or $\left.\mathrm{O}^{-}\right)$, $\mathrm{OH}$ groups and oxygen vacancies (531.2-531.5 $\mathrm{eV}$ ), and adsorbed molecular water (532.0-532.5 eV) is indicated by two shoulders [17,27].

The oxidation states and relative amounts of various $\mathrm{Mn}$ species in each oxide were ascertained by analysing Mn $2 p$ and Mn 3s X-ray core level photoelectron spectra. Fig. 3(b) and (c) present the Mn $2 p$ and Mn $3 s$ spectra of the Mn1. The Mn $2 p_{3 / 2}$ and Mn $2 p_{1 / 2}$ centroid between 642.6 and $654.4 \mathrm{eV}$ provides evidence for the formation of the cryptomelane phase, in agreement with reported values [28,29]. Although it was difficult to identify the oxidation states, the binding energy shifts in the Mn $2 p$ and Mn $3 s$ regions can provide some information. In particular, the magnitude of the Mn3s multiplet splitting can be used to calculate the average oxidation state (AOS) of manganese, according to the relationship AOS $=8.95-1.13 \Delta E_{\mathrm{s}}(\mathrm{eV})$ where $\Delta E_{\mathrm{s}}$ represents the extent of multiplet splitting (the distance between the main peak and its satellite) [30]. Fig. 4(b) shows the Mn $3 s$ spectra for the prepared manganese oxides highlighting the $\Delta E_{\mathrm{s}}$ parameter. Table 2 summarizes the corresponding AOS values. It is evident that samples prepared by the

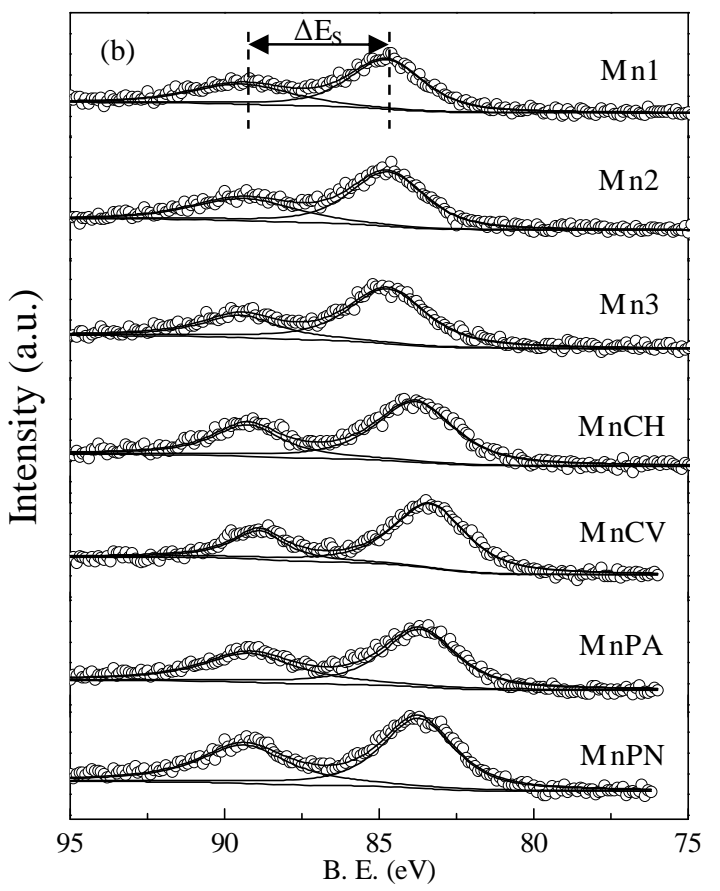

Fig. 4. The Mn $2 p$ (a) and Mn $3 s$ (b) XPS spectra of the manganese oxides. 
solvent-free reaction and reflux methods (Mn1, Mn2 and Mn3) had higher AOS values (3.6-3.7) while the oxides obtained using the conventional methods had lower values (2.6-2.8). All specimens generated similar Mn $2 p$ core level spectra (Fig. $4(\mathrm{a})$ ). Based on the theoretical oxidation numbers of manganese stabilized as $\mathrm{KMn}_{8} \mathrm{O}_{12}, \mathrm{MnO}_{2}, \mathrm{Mn}_{3} \mathrm{O}_{4}, \mathrm{Mn}_{5} \mathrm{O}_{8}$ and $\mathrm{Mn}_{2} \mathrm{O}_{3}$ (the crystalline phases identified by XRD) and the relative proportions of these different phases as reported in Table 1, the average bulk oxidation states for the manganese samples as determined by XRD show a maximum deviation of $8 \%$ relative to the AOS values calculated from XPS data. Thus there is good agreement between the results obtained from both techniques. As an example, the MnPN was found to contain $95 \% \mathrm{Mn}_{3} \mathrm{O}_{4}$ and $5 \% \mathrm{Mn}_{5} \mathrm{O}_{8}$, corresponding to an average bulk oxidation state of $2.7[95 \% \times(+2.67)+5 \% \times(+3.2)]$, while an AOS of 2.6 was calculated using the XPS results.

$\mathrm{H}_{2}$-TPR experiments were performed to evaluate the reactivity of $O$ species in these materials with hydrogen (that is, the reducibility of the catalysts). Fig. 5 provides the TPR profiles of the different materials, each of which is characterized by the presence of overlapping components between 200 and $500{ }^{\circ} \mathrm{C}$. However, there are evident differences between the Mn1, Mn2 and Mn3 (samples prepared by the solvent-free and reflux methods) and $\mathrm{MnCH}, \mathrm{MnCV}, \mathrm{MnPA}$ and MnPN (produced by conventional methods). In the first group, the TPR profiles are narrower, with hydrogen consumption between 200 and 375 ${ }^{\circ} \mathrm{C}$, and exhibit intense peaks with maxima in the range of $300-350{ }^{\circ} \mathrm{C}$. The remaining samples $(\mathrm{MnCH}, \mathrm{MnCV}, \mathrm{MnPA}$ and $\mathrm{MnPN}$ ) produced TPR profiles that are wider and in which the major peaks appear at higher temperatures. In keeping with the results of the XRD and XPS analyses, these data suggest that the oxides contain a variety of crystalline phases that significantly affect their reducibility. Furthermore, the data in Table 1 demonstrate that both the onset of reduction and the maximum temperature of the most intense reduction peak increase as the average oxidation state decreases (Table 2). Table 1 also shows that a greater degree of hydrogen consumption was exhibited by the Mn1, Mn2 and Mn3.

The hydrogen consumption of the Mn1 begins at approximately $250{ }^{\circ} \mathrm{C}$, while the consumption onset associated with the $\mathrm{Mn} 2$ and $\mathrm{Mn} 3$ is shifted to lower temperatures $\left(<200^{\circ} \mathrm{C}\right)$.

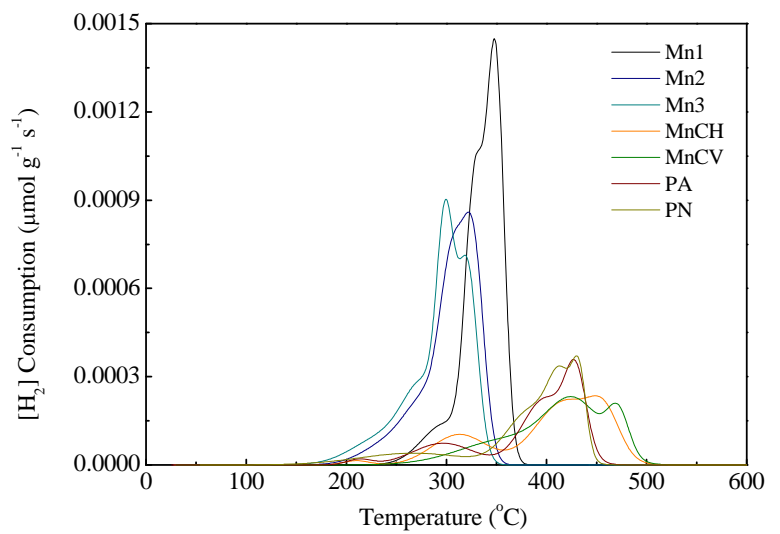

Fig. 5. TPR profiles of the manganese oxides.
The low specific surface area of the Mn1 may explain the relatively high temperature of the first reduction step [31]. These results clearly indicate that the Mn2 and Mn3 were reduced more readily than the $\mathrm{Mn} 1$.

Comparing the TPR profiles of the $\mathrm{MnCH}, \mathrm{MnCV}, \mathrm{MnPA}$ and $\mathrm{MnPN}$, the temperature for the onset of reduction is similar for each. In addition, the temperature of the most intense reduction peak is much higher in these samples, while their hydrogen consumption values are significantly lower.

\subsection{Catalytic tests}

Both ethyl and butyl acetate were oxidized over the manganese oxide materials to evaluate the effects of the oxide physical and chemical properties on catalytic performance. Temperature programmed experiments (so-called "light-off curves") were employed for rapid screening. In this type of test, the catalysts with the highest performance can be identified based on achieving a specific conversion value at a lower temperature. These trials also demonstrated that each of the oxides was highly stable. Each test consisted of two cycles increasing and decreasing temperature at a heating/cooling rate of $2.5{ }^{\circ} \mathrm{C}$ $\mathrm{min}^{-1}$ and the catalytic performance was very similar during the increasing and decreasing temperature steps. The oxide catalysts were compared based on the results obtained during the decreasing temperature cycle, and the catalytic performance is plotted as functions of reaction temperature in Figs. 6 and 7 . Table 3 gives the temperatures required to achieve $50 \%$ $\left(T_{50}\right)$ and $90 \%\left(T_{90}\right)$ conversions of ethyl acetate and butyl acetate to $\mathrm{CO}_{2}$. Each of the materials exhibited activity during the VOC oxidation reactions, although the catalytic performance varied depending on the preparation method. The following trend was observed with regard to decreasing performance: $\mathrm{Mn} 2 \approx \mathrm{Mn} 3>\mathrm{Mn} 1>\mathrm{MnPA}>\mathrm{MnPN}>\mathrm{MnCV} \approx \mathrm{Mn}$ CH. The data show that the $T_{90}$ values were between 213 and $265{ }^{\circ} \mathrm{C}$, and between 202 and $265^{\circ} \mathrm{C}$ for ethyl acetate and butyl acetate, respectively.

The catalytic activity of manganese oxides during VOC oxidation is typically determined by the manganese oxidation

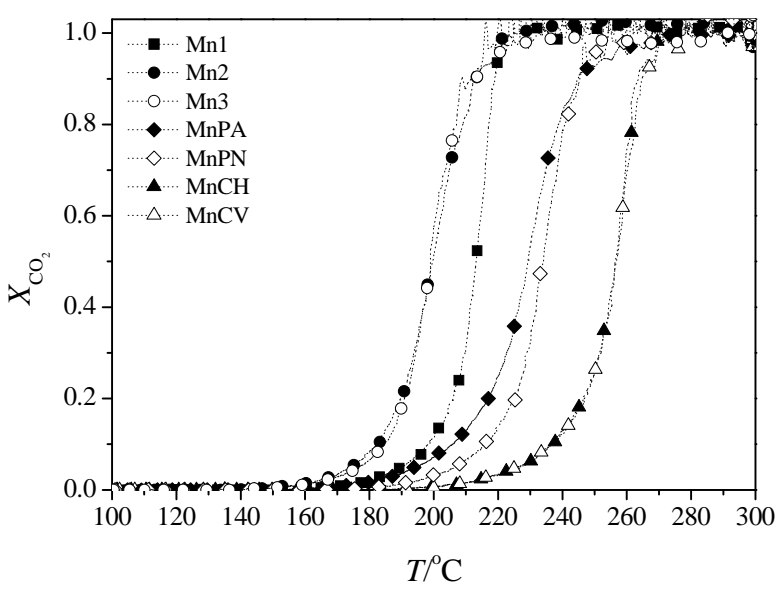

Fig. 6. Conversion to $\mathrm{CO}_{2}$ as a function of temperature during ethyl acetate oxidation. 


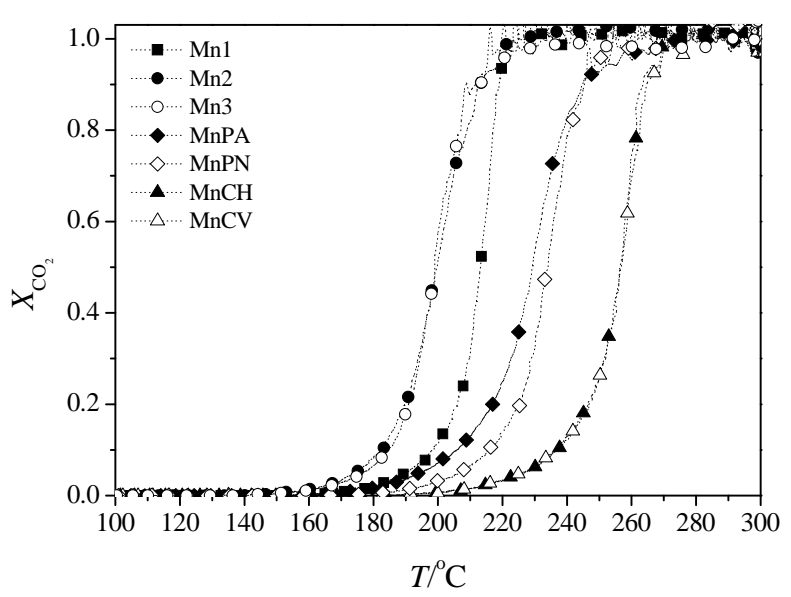

Fig. 7. Conversion to $\mathrm{CO}_{2}$ as a function of temperature during butyl acetate oxidation.

state, lattice oxygen content, degree of crystallinity, specific surface area or even reducibility. However, the results obtained in this study do not provide evidence for a clear correlation between catalytic performance and the various properties of the catalysts. As an example, the performance of these materials cannot be related to the surface area, as samples Mn2 and Mn3 (both prepared by solid-state reaction) show essentially the same level of activity in spite of their different surface areas. In addition, the Mn1 and MnPA have the same surface area but significantly different catalytic abilities. Therefore, these variations in performance must be related to the manganese oxide species present on the catalyst surface, and consequently to the AOS value. It is well established that the oxidation of organic molecules over manganese oxide catalysts at low temperatures involves a Mars-van-Krevelen mechanism [5,10,14] that includes a redox cycle on the catalyst surface with the participation of lattice oxygen. The involvement of lattice oxygen in the VOC oxidation process can be evaluated by experiments without oxygen in the feed. Thus, additional oxidation experiments were performed, in which the air was replaced with nitrogen. In these trials, following the pre-treatment step, the reactor was purged with nitrogen to remove physisorbed oxygen. Subsequently, the reactions were performed using the same VOC composition as in the oxidation reactions, and the resulting $\mathrm{CO}_{2}$ was measured. If VOC oxidation is observed un- der such conditions, this demonstrates the involvement of lattice oxygen. The highest $\mathrm{CO}_{2}$ releases during these experiments, for both VOCs, were obtained using samples prepared by the solvent-free and reflux approaches. In the case of ethyl acetate oxidation, the $\mathrm{CO}_{2}$ production varied between 576 and 705 $\mu \mathrm{mol} \mathrm{g}{ }^{-1}$ when using the Mn1, Mn2 and Mn3, compared with values of 120 to $499 \mu \mathrm{mol} \mathrm{g}^{-1}$ when using the MnPA, MnPN, $\mathrm{MnCH}$ and MnCV. The oxidation of butyl acetate gave the same trend, with 320 to $541 \mu \mathrm{mol} \mathrm{g}^{-1} \mathrm{CO}_{2}$ formed using the $\mathrm{Mn} 1$, $\mathrm{Mn} 2$ and Mn3 and only between 59 and $151 \mu \mathrm{mol} \mathrm{g}{ }^{-1}$ resulting from the MnPA, MnPN, MnCH and MnCV.

These experiments also confirmed that the oxides with the highest oxidation states exhibit the best oxidation activities. In fact, a trend can be observed in Fig. 8(a) and (b) in which the $\mathrm{Mn} 1, \mathrm{Mn} 2$ and Mn3 (having the highest AOS values of 3.6-3.7) are the most active and thus show the lowest $T_{90}$ values for ethyl and butyl acetate. Conversely, the MnPA, MnPN, MnCH and $\mathrm{MnCV}$ (with lower AOS values of 2.6-2.8) require higher temperatures for the complete oxidation of the esters. This is closely related to the two different types of samples prepared: one with and another without cryptomelane-type manganese oxides. Due to the close AOS values of the two groups of samples, a clear differentiation of their performances based exclusively on this parameter is not possible. For instance, samples Mn1 and Mn2 have the same AOS but slightly different catalytic performance. Therefore, it can be concluded that the performance of these samples must also be related to the presence of small amounts of $\alpha-\mathrm{MnO}_{2}$, as detected by XRD analyses of the $\mathrm{Mn} 1$ and $\mathrm{Mn} 3$, in contrast with the Mn2, which was purely cryptomelane.

In a previous study, Luo et al. [21] attributed the superior catalytic performance of cryptomelane materials to their strong affinity for organic compounds. In a later work, Chen et al. [32] suggested that the elevated activity of cryptomelane was due to the tunnel structure of this phase, which promotes the adsorption of organic compounds and the subsequent reaction. However, the presence of other phases significantly affects the cryptomelane performance. As an example, Santos et al. [17] observed that the presence of $\mathrm{Mn}_{3} \mathrm{O}_{4}$ improves the catalytic performance of cryptomelane due to the increased the mobility of lattice oxygen, while the $\mathrm{Mn}_{2} \mathrm{O}_{3}$ phase has the opposite effect. A qualitative evaluation of the present catalytic results confirms that samples with a cryptomelane structure (Mn1, Mn2

Table 3

Catalytic performances of the manganese oxides as indicated by the temperatures required to achieve $50 \%$ and $90 \%$ conversions of ethyl acetate (EtAC) and butyl acetate (BtAc) to $\mathrm{CO}_{2}\left(T_{50}\right.$ and $\left.T_{90}\right)$.

\begin{tabular}{|c|c|c|c|c|c|c|c|c|}
\hline \multirow{3}{*}{ Sample } & \multicolumn{4}{|c|}{ EtAc } & \multicolumn{4}{|c|}{ BtAc } \\
\hline & \multicolumn{2}{|c|}{$X\left[\mathrm{CO}_{2}\right]$} & \multicolumn{2}{|c|}{$X[$ EtAc $]$} & \multicolumn{2}{|c|}{$X\left[\mathrm{CO}_{2}\right]$} & \multicolumn{2}{|c|}{$X[\mathrm{BtAc}]$} \\
\hline & $T_{50}\left({ }^{\circ} \mathrm{C}\right)$ & $T_{90}\left({ }^{\circ} \mathrm{C}\right)$ & $T_{50}\left({ }^{\circ} \mathrm{C}\right)$ & $T_{90}\left({ }^{\circ} \mathrm{C}\right)$ & $T_{50}\left({ }^{\circ} \mathrm{C}\right)$ & $T_{90}\left({ }^{\circ} \mathrm{C}\right)$ & $T_{50}\left({ }^{\circ} \mathrm{C}\right)$ & $T_{90}\left({ }^{\circ} \mathrm{C}\right)$ \\
\hline$\overline{M n 1}$ & 213 & 219 & 213 & 219 & 210 & 228 & 190 & 207 \\
\hline $\mathrm{Mn} 2$ & 200 & 213 & 198 & 213 & 188 & 202 & 175 & 196 \\
\hline Mn3 & 200 & 213 & 198 & 213 & 190 & 208 & 171 & 194 \\
\hline $\mathrm{MnPA}$ & 229 & 245 & 229 & 249 & 218 & 233 & 151 & 180 \\
\hline $\mathrm{MnPN}$ & 234 & 245 & 232 & 245 & 229 & 251 & 210 & 233 \\
\hline $\mathrm{MnCH}$ & 256 & 263 & 256 & 264 & 249 & 265 & 220 & 255 \\
\hline $\mathrm{MnCV}$ & 257 & 265 & 256 & 266 & 244 & 255 & 214 & 245 \\
\hline
\end{tabular}



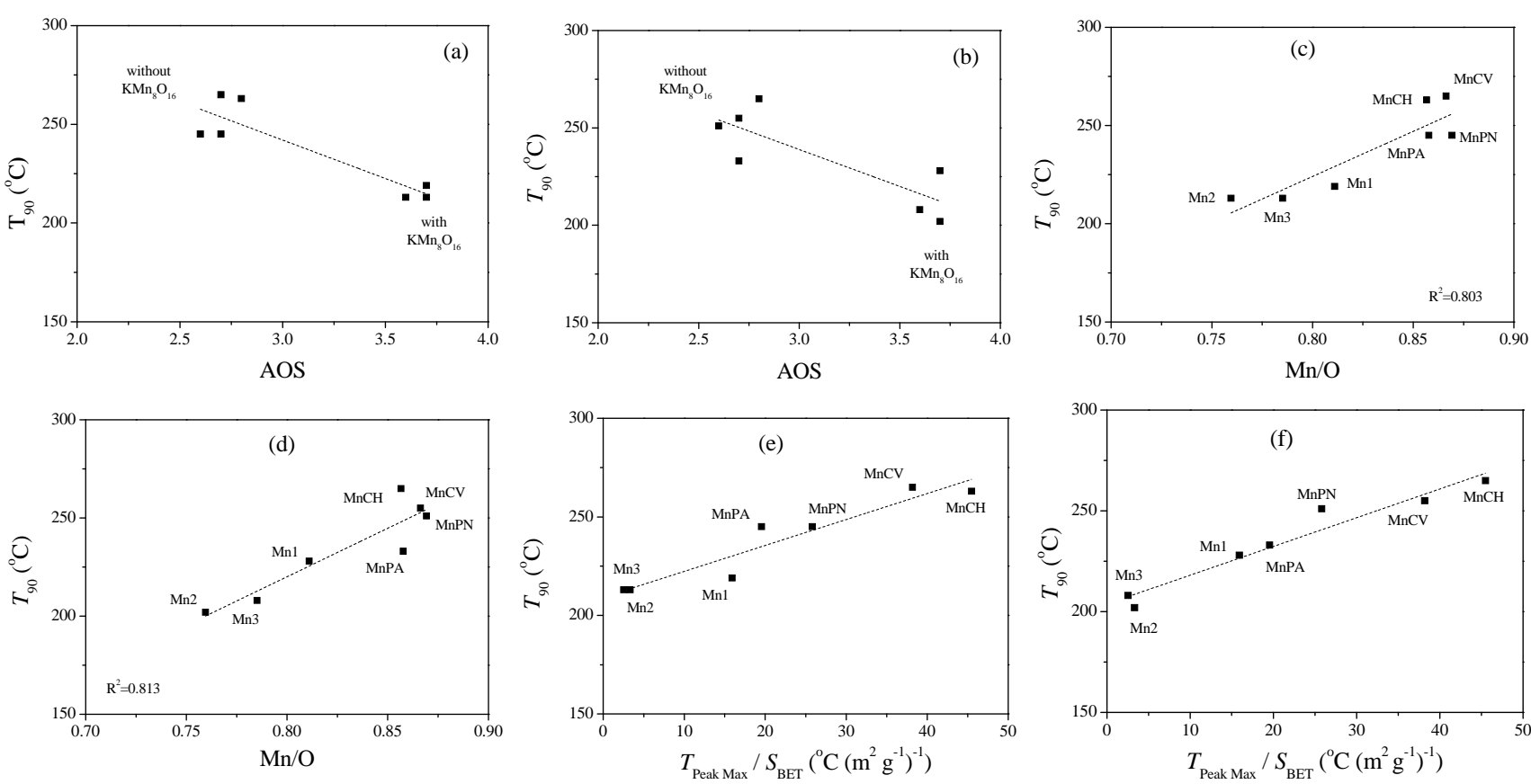

Fig. 8. $T_{90}$ values for the oxidation of ethyl acetate $(a, c, e)$ and butyl acetate $(b, d, f)$ as functions of AOS (a, b), the Mn/O ratio (c, d) and the temperature of the most intense peak obtained from TPR normalized by the specific surface area $(e, f)$.

and Mn3) had the best catalyst performance. Furthermore, it appears that the presence of $\alpha-\mathrm{MnO}_{2}$ may negatively affect performance. Comparing the samples with low AOS values ( $\mathrm{MnCH}, \mathrm{MnCV}, \mathrm{MnPA}$ and MnPN) and a mixture of phases, it can be concluded that the presence of $\alpha-\mathrm{Mn}_{2} \mathrm{O}_{3}$ decreases the catalytic performance.

Nevertheless, a close correlation between the VOC oxidation performance and the $\mathrm{Mn} / 0$ ratios calculated from XPS data is evident in Fig. 8(c) and (d), demonstrating the important role of surface oxygen in the catalytic performance of the samples. The oxide with the lowest $\mathrm{Mn} / 0$ ratio (Mn2) had the highest activity, while the materials prepared by the conventional methods and having the highest $\mathrm{Mn} / 0$ ratios produced the highest $T_{90}$ values (i.e., had the lowest activities).

A strong relationship between $T_{90}$ and the reduction temperature of the most intense peak normalized by the surface area is also apparent (Fig. 8(e) and (f)). This parameter,

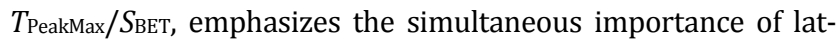
tice oxygen (hence reducibility) and available surface area on the catalytic oxidation of the VOCs. Accordingly, the samples with the lowest reduction temperatures showed higher catalytic activities and required lower temperatures for the total oxidation of ethyl and butyl acetate. Previous works [11,33,34] have also demonstrated a relationship between the catalytic performance and the reducibility of the catalysts, which is in agreement with the results obtained in this work. These findings confirm that the oxidation of the VOCs proceeds via the Mars-van-Krevelen mechanism, such that the surface lattice oxygen of the catalysts is involved in the reaction with the VOC. As a result, the reducibility of the material is an important factor.

The samples prepared in this work by the novel solvent-free method and reflux approach had higher amounts of surface lattice oxygen (as indicated by the $\mathrm{O}_{\mathrm{I}}$ peak intensities) and lower reduction temperatures compared with the oxides obtained using conventional methods. However, comparing the $\mathrm{Mn} 1$ and Mn2, it can be concluded that the catalytic performance is not determined solely by the concentration of surface lattice oxygen, because the Mn1 contained more of this type of oxygen but showed slightly lower performance than the Mn2.

In summary, it is evident that the surface chemistry of the two sets of samples was more important than the textural properties in determining catalytic performance during VOC oxidation, although no direct correlations can be shown for each individual parameter. The data also show that an efficient manganese oxide catalyst (Mn2) was prepared using the solvent-free technique and could have applications as an alternative to the noble metal catalysts more typically used in the oxidation of VOCs.

\subsection{Stability tests}

Prolonged use experiments were carried out with the Mn2 to examine the stability of the catalyst. This specimen was selected due to its high catalytic performance. The conversions of ethyl acetate and butyl acetate at 210 and $200{ }^{\circ} \mathrm{C}$ as a function of time are plotted in Fig. 9(a) and (b), respectively. These reaction temperatures were employed to achieve a high initial VOC conversion of approximately $90 \%$. The ethyl acetate conversion evidently increased by $13 \%$ over a span of $150 \mathrm{~h}$, while the catalyst remained stable during butyl acetate oxidation over approximately $180 \mathrm{~h}$, showing a conversion of $90 \%$ over the entire test. Similar stability behaviour was also observed when assessing conversion to $\mathrm{CO}_{2}$. 

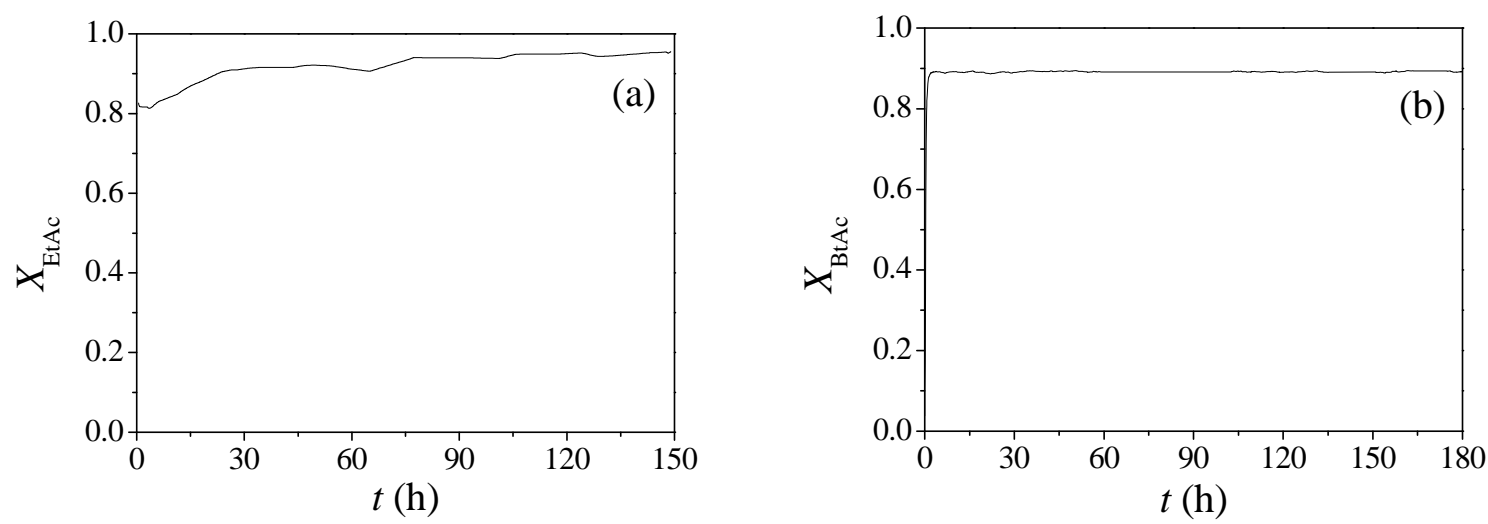

Fig. 9. The VOC conversion as a function of time using the $\mathrm{Mn} 2$ during the oxidation of ethyl acetate at $210{ }^{\circ} \mathrm{C}$ (a) and butyl acetate at $200{ }^{\circ} \mathrm{C}$ (b).

\section{Conclusions}

Manganese oxides were synthesized by different methods. The preparation methodology was found to play an important role in determining the catalytic performance, although each of the oxides was highly active during the oxidation of ethyl acetate or butyl acetate to $\mathrm{CO}_{2}$. The catalysts prepared by the reflux and solid state reaction methods, all of which contained a cryptomelane phase, were the most active. In addition, the cryptomelane-type manganese oxide obtained using the novel solvent-free technique showed superior performance to that prepared by the conventional reflux approach. Grinding of the precursor by ball-milling allows controlled and reproducible synthesis of cryptomelane manganese oxide, which is typically challenging when using manual grinding in a mortar. Significant differences in catalytic performances were observed between the various specimens. This variation indicates that the performance is related to the ability of the material to donate lattice oxygen at the catalyst surface, as well as to reducibility, average oxidation state and available surface area. The manganese oxide catalyst prepared by the solid state reaction method also exhibited good stability during prolonged usage.

\section{Acknowledgments}

The authors thank Dr. Carlos Sá at CEMUP for assistance with XPS analyses and to Dr. Carla Orge for providing the samples MnPA and MnPN used in this work.

\section{References}

[1] M. S. Kamal, S. A. Razzak, M. M. Hossain, Atmos. Environ., 2016, $140,117-134$.

[2] H. B. Huang, Y. Xu, Q. Y. Feng, D. Y. C. Leung, Catal. Sci. Technol., 2015, 5, 2649-2669.

[3] J. Tsou, L. Pinard, P. Magnoux, J. L. Figueiredo, M. Guisnet, Appl. Catal. B, 2003, 46, 371-379.

[4] F. N. Aguero, B. P. Barbero, M. F. R. Pereira, J. L. Figueiredo, L. E. Cadus, Ind. Eng. Chem. Res., 2009, 48, 2795-2800.

[5] V. P. Santos, M. F. R. Pereira, J. J. M. Órfão, J. L. Figueiredo, Top. Catal., 2009, 52, 470-481.
[6] M. A. Peluso, J. E. Sambeth, H. J. Thomas, React. Kinet. Catal. Lett., 2003, 80, 241-248.

[7] E. Finocchio, G. Busca, Catal. Today, 2001, 70, 213-225.

[8] V. P. Santos, M. F. R. Pereira, J. J. M. Órfão, J. L. Figueiredo, Appl. Catal. B, 2009, 88, 550-556.

[9] K. Everaert, J. Baeyens, J. Hazard. Mater., 2004, 109, 113-139.

[10] M. Baldi, E. Finocchio, F. Milella, G. Busca, Appl. Catal. B, 1998, 16, 43-51.

[11] S. S. T. Bastos, J. J. M. Órfão, M. M. A. Freitas, M. F. R. Pereira, J. L. Figueiredo, Appl. Catal. B, 2009, 93, 30-37.

[12] S. L. Suib, J. Mater. Chem., 2008, 18, 1623-1631.

[13] L. Lamaita, M. A. Peluso, J. E. Sambeth, H. J. Thomas, Appl. Catal. B, 2005, 61, 114-119.

[14] C. Cellier, V. Ruaux, C. Lahousse, P. Grange, E. M. Gaigneaux, Catal. Today, 2006, 117, 350-355.

[15] M. A. Peluso, L. A. Gambaro, E. Pronsato, D. Gazzoli, H. J. Thomas, J. E. Sambeth, Catal. Today, 2008, 133, 487-492.

[16] C. Lahousse, A. Bernier, E. Gaigneaux, P. Ruiz, P. Grange, B. Delmon, Stud. Surf. Sci. Catal., 1997, 777-785.

[17] V. P. Santos, M. F. R. Pereira, J. J. M. Órfão, J. L. Figueiredo, Appl. Catal. B, 2010, 99, 353-363.

[18] C. T. Wong, A. Z. Abdullah, S. Bhatia, J. Hazard. Mater., 2008, 157, 480-489.

[19] S. Qjala, U. Lassi, M. Harkonen, T. Maunula, R. Silvonen, R. L. Keiski, Chem. Eng.J., 2006, 120, 11-16.

[20] P. Papaefthimiou, T. Ioannides, X. E. Verykios, Appl. Catal. B, 1997, $13,175-184$

[21] J. Luo, Q. H. Zhang, A. M. Huang, S. L. Suib, Microporous Mesoporous Mater., 2000, 35-36, 209-217.

[22] Y. F. Shen, R. P. Zerger, R. N. DeGuzman, S. L. Suib, L. McCurdy, D. I. Potter, C. L. O'Young, Science, 1993, 260, 511-515.

[23] Y. S. Ding, X. F. Shen, S. Sithambaram, S. Gomez, R. Kumar, V. M. B. Crisostomo, S. L. Suib, M. Aindow, Chem. Mater., 2005, 17, 5382-5389.

[24] C. A. Orge, J. J. M. Órfão, M. F. R. Pereira, J. Hazard. Mater., 2012, 213-214, 133-139.

[25] N. Birkner, A. Navrotsky, Proc. Nat. Acad. Sci. USA, 2017, 114, E1046-E1053.

[26] F. Schurz, J. M. Bauchert, T. Merker, T. Schleid, H. Hasse, R. Gläser, Appl. Catal. A, 2009, 355, 42-49.

[27] S. C. Kim, W. G. Shim, Appl. Catal. B, 2010, 98, 180-185.

[28] X. F. Shen, A. M. Morey, J. Liu, Y. S. Ding, J. Cai, J. Durand, Q. Wang, W. Wen, W. A. Hines, J. C. Hanson, J. M. Bai, A. I. Frenkel, W. Reiff, M. Aindow, S. L. Suib, J. Phys. Chem. C, 2011, 115, 21610-21619.

[29] V. P. Santos, O. S. G. P. Soares, J. J. W. Bakker, M. F. R. Pereira, J. J. M. 


\title{
Graphical Abstract
}

Chin. J. Catal., 2018, 39: 27-36 doi: 10.1016/S1872-2067(17)62986-3

\section{Ethyl and butyl acetate oxidation over manganese oxides}

Olívia Salomé G. P. Soares, Raquel P. Rocha, José J. M. Órfão, Manuel F. R. Pereira, José L. Figueiredo* University of Porto, Portugal

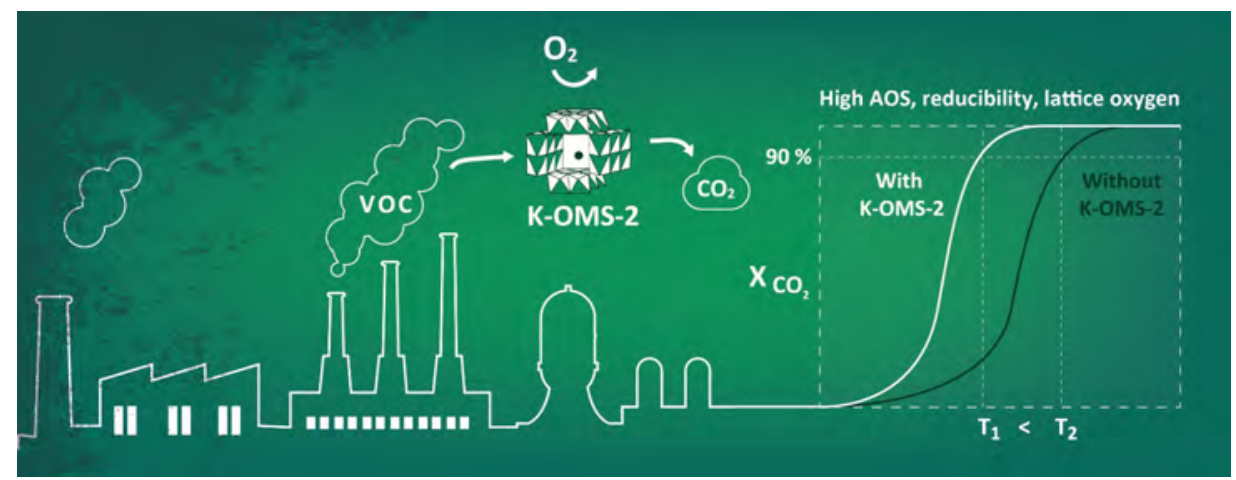

During trials involving the oxidation of ethyl acetate and butyl acetate over manganese oxide catalysts, samples containing a cryptomelane phase and synthesized by a novel solvent-free method showed higher catalytic performance.

Órfão, J. Gascon, F. Kapteijn, J. L. Figueiredo, J. Catal., 2012, 293, 165-174.

[30] V. R. Galakhov, M. Demeter, S. Bartkowski, M. Neumann, N. A. Ovechkina, E. Z. Kurmaev, N. I. Lobachevskaya, Y. M. Mukovskii, J. Mitchell, D. L. Ederer, Phys. Rev. B, 2002, 65, 113102/1-113102/4.

[31] F. Kapteijn, L. Singoredjo, A. Andreini, J. A. Moulijn, Appl. Catal. B, 1994, 3, 173-189.
[32] T. Chen, H. Y. Dou, X. L. Li, X. F. Tang, J. H. Li, J. M. Hao, Microporous. Mesoporous. Mater., 2009, 122, 270-274.

[33] S. A. C. Carabineiro, M. Konsolakis, G. E. N. Marnellos, M. F. Asad, O. Soares, P. B. Tavares, M. F. R. Pereira, J. J. M. Órfão, J. L. Figueiredo, Molecules, 2016, 21, 644/1-644/20.

[34] X. Chen, S. A. C. Carabineiro, S. S. T. Bastos, P. B. Tavares, J. J. M. Órfão, M. F. R. Pereira, J. L. Figueiredo, Appl. Catal. A, 2014, 472, 101-112.

\section{氧化镁上乙酸乙酯和乙酸丁酯氧化反应}

\author{
Olívia Salomé G. P. Soares, Raquel P. Rocha, José J. M. Órfão, Manuel F. R. Pereira, \\ José L. Figueiredo * \\ 波尔图大学工程学院分离与反应工程实验室-催化与材料实验室(LSRE-LCM), Rua Dr. Roberto Frias s/n, \\ 波尔图4200-465，葡萄牙
}

\begin{abstract}
摘要: 采用新型无溶剂反应和回流的方法制得锰钾矿型氧化镁(K-OMS-2), 同时采用常规方法制得氧化美, 并测试不同催 化剂对工业排放气中有机挥发性物质(VOCs)中的模型化合物一乙酸乙酯和乙酸丁酯的催化氧性能. 采用 $\mathrm{N}_{2}$ 吸附-脱附、 $\mathrm{X}$ 射线衍射、扫描电镜、程序升温还原和X射线光电子能谱等技术对催化剂进行了表征. 所有氧化镁样品均表现出很高的催 化乙酸乙酯和乙酸丁酯氧化生成 $\mathrm{CO}_{2}$ 的活性, 且制备方法对催化剂性能起着重要作用. 新型无溶剂法制得的K-OMS-2纳米 棒样品比常规的回流法制得样品表现出更好的催化性能, 含锰钾矿型氧化镁的样品比常规方法制得样品表现出更高的活 性. 性能最好的催化剂也表现出较高的稳定性, 在 213 和 $202{ }^{\circ} \mathrm{C}$ 条件下, 可分别使 $90 \%$ 的乙酸乙酯和乙酸丁酯转化为 $\mathrm{CO}_{2}$. 催化剂性能的显著差异清楚地表明, 对于所选VOCs氧化反应, 采用新型无溶剂法制得的K-OMS-2纳米棒样品比常规法制 备的氧化镁混合物更好, 这可能与样品结构中含有更高的Mn平均氧化态有关. 本文表明了催化剂性能与其表面化学性质 间存在显著的关联, 显示了K-OMS-2内在性质决定了其高的催化性能.
\end{abstract} 关键词: 挥发性有机化合物; 乙酸乙酯; 乙酸丁酯; 氧化镁; 催化氧化

收稿日期: 2017-11-07. 接受日期: 2017-11-21. 出版日期: 2018-01-05.

*通讯联系人. 电话: +351-225-081998; 传真: +351-225-081449; 电子信箱: jlfig@fe.up.pt 本文的电子版全文由Elsevier出版社在ScienceDirect上出版(http://www.sciencedirect.com/science/journal/18722067). 